\title{
The Success of Currency Reforms to End Great Inflations: An Empirical Analysis of 34 High Inflations
}


The Author(s):

Prof. Dr. Peter Bernholz

Center of Business and Economics (WWZ), University of Basel

Petersgraben 51

CH-4051 Basel

peter.bernholz@unibas.ch

\section{Prof. Dr. Peter Kugler}

Center of Business and Economics (WWZ), University of Basel

Petersgraben 51

CH-4051 Basel

peter.kugler@unibas.ch

A publication oft the Center of Business and Economics (WWZ), University of Basel.

(C) WWZ Forum 2007 and the author(s). Reproduction for other purposes than the personal use needs the permission of the author(s).

\section{Contact:}

WWZ Forum | Petersgraben 51 | CH-4003 Basel | forum-wwz@unibas.ch |www.wwz.unibas.ch 


\title{
The Success of Currency Reforms to End Great Inflations: An Empirical Analysis of 34 High Inflations
}

\author{
Peter Bernholz and Peter Kugler \\ WWZ /University of Basel
}

\begin{abstract}
The estimation of an ordered probit model for currency reforms trying to end 31 hyperinflations and three big inflations of the $20^{\text {th }}$ century shows that the introduction of an independent central bank and the adoption of a credibly fixed exchange rate are crucial for the success of a currency reform. In addition, currency reforms are demonstrated to be more difficult in centrally planned economies than in market economies.
\end{abstract}

JEL: E31, E58, E65

Key words: Great inflations, currency reforms, central bank independence, fixed exchange rate

November 2006

Revised August 2007

Corresponding author:

Peter Kugler, WWZ Universität Basel, Petersgraben 51, CH-4003 Basel, Peter.kugler@unibas.ch 


\section{Introduction}

To end very high inflations and even hyperinflations in Cagan`s definition (1956), that is of inflations rising to rates of $50 \%$ per month or more, without causing severe economic disruptions has proved to be a difficult task. The government deficit is huge and increasing and mainly financed by creating money. Moreover, government and monetary authorities have lost all credibility. The public try frenetically to get rid of the national money and to substitute it by stable foreign or (formerly) gold or silver money. Thus rates of inflation are surging ahead of the growth of the money supply, the real stock of the national money is far below its normal level and the exchange rate is strongly undervalued. Capital markets have fallen apart and the real economy is in a mess. The social consequences of differently falling real wages in the diverse sectors of the economy and of the elimination of the value of nominal assets are devastating. As a consequence ruling politicians and often even political regimes are discredited, a fact which has led in most cases to a fall of the government or even to the emergence of authoritarian regimes (Paldam 1994).

But in spite of these adverse conditions it has been possible in several cases to reestablish stable national currencies without severe increases of unemployment and with beneficial consequences for the real economy. This has been clearly shown by Sargent (1982) for four central European hyperinflations of the 1920s (compare also Makinen 1984 for the Greek stabilization of 1946, and Bomberger and Makinen 1983 for the Hungarian stabilization 1946). On the other hand, quite a number of reforms ending hyperinflations have been far less successful than the four mentioned by Sargent. This raises the question which institutional reforms are necessary or even sufficient for successful reforms. According to Makinen (1992, see also Cagan 1992, p. 325)

Experience has shown that successfully ending hyperinflations requires a public sector budget balanced by explicit taxes and an end to money finance. It also suggests that to enforce fiscal responsibility, monetary policy has to be constrained by actions such as those creating an independent central bank, restoring external currency convertibility, or submitting domestic policy to foreign supervision. (p. 328)

These are certainly correct observations, but leave open several questions. First, they do not answer the question under which conditions the reform may be politically feasible. Second, it does not address the problem, how the seeming contradiction between the necessity to strongly increase the real stock of the national money, given its very low level, and the control of the money supply can be resolved by the reforms. And finally, it leaves the question open which of the factors mentioned are necessary and which are only supplementary conditions for the most successful 
reforms. Subsequently we will try to answer the latter question by a comparative econometric analysis for a sample of all 31 hyperinflations which occurred until now in history and three additional high inflations.

\section{Description of 34 High Inflations}

A few years ago Bernholz (2003, pp. 166 - 193) tried to answer the questions just asked by a qualitative comparative analysis of all hyperinflations, and by considering four failed additional reforms of high inflations (pp. 189 ff.). He divided the attempted reforms of the 30 hyperinflations (Table 2.1) into three categories depending on the remaining rates of inflation in the year following the reform. The first category of the most successful reforms comprised the nine historical cases in which the rate of inflation remained below $25 \%$. The second category of less successful reforms with seven cases referred to remaining rates of inflation between 25 and $99 \%$. And the last category of least successful currency reforms contained fourteen cases in which the rate of inflation remained higher than $99 \%$ or which failed altogether. Since such a classification is somewhat arbitrary we checked the robustness of our result by also using a $10 \%$ besides the $25 \%$ bound for the most successful currency reforms. For the subsequent quantitative analysis we have added three additional cases of attempted currency reforms: The Israeli reform of 1985 and the Argentine (plan Austral) and Brazilian (plan Cruzado) reforms in 1985 and 1986. These three reforms tried to end high inflations below the hyperinflation level. In Greece two reforms were tried to end the hyperinflation of World War II. The first effort in 1944 was not successful, whereas this was the case for the second reform in the beginning of 1946. Table 2.1 presents the highest monthly inflation rates reached in these 34 historical cases and also the annual rates of inflation remaining in the time following the attempted reforms. 
Table 1: All Hyperinflations and Three Other 20th Century High Inflations

\begin{tabular}{|c|c|c|c|c|c|c|c|}
\hline Country & Year(s) & Highest Infla- & $\begin{array}{l}\text { Annual } \\
\text { Infla- }\end{array}$ & Country & Year(s) & $\begin{array}{l}\text { Highest } \\
\text { Infla- }\end{array}$ & Annual Infla- \\
\hline & & tion p. Month & tion in Year & & & $\begin{array}{l}\text { tion p. } \\
\text { Month }\end{array}$ & tion in Year \\
\hline & & & after Reform & & & & after Reform \\
\hline Austria & $1921 / 22$ & 124.27 & 3.83 & Hungary I & $1923 / 24$ & 82.18 & -6.33 \\
\hline Argentina & $1985 / 86$ & 30.64 & 50.9 & Hungary II & $1945 / 46$ & $1.295 \mathrm{E}+16$ & 40.91 \\
\hline Argentina & 1989/90 & 196.6 & 84 & Israel & 1984/85 & 21.7 & 21.26 \\
\hline Armenia & 1993/94 & 438.04 & 177.78 & Kazakhstan & 1994 & 57 & 177.01 \\
\hline Azerbaijan & $1991 / 94$ & 118.09 & 322.2 & Kyrgyzstan & 1992 & $54.17 *$ & 383.77 \\
\hline Belarus & 1999 & '59,5* & 161 & Moldova & 1992 & $170,98 *$ & 83.3 \\
\hline Bolivia & 1984/86 & 120.39 & 19.4 & Nicaragua & 1986/89 & 126.62 & 3.5 \\
\hline Brazil I & $1985 / 86$ & 21.83 & 72.8 & Peru & 1989 & 104.14 & 73.33 \\
\hline Brazil II & 1989/90 & 84.32 & 84.38 & Poland I & $1921 / 24$ & 187.54 & 24.48 \\
\hline Bulgaria & 1997 & 242.7 & 2.93 & Poland II & 1989/90 & 77.33 & 62.22 \\
\hline China & $1947 / 49$ & 4208.73 & 11248955 & Serbia & 1992/94 & 309000000 & 100 \\
\hline $\begin{array}{l}\text { Congo } \\
\text { (Zaire) }\end{array}$ & 1991/93 & 124.3 & 598.37 & Soviet Union & $1922 / 24$ & 278.72 & -0.5 \\
\hline France & 1789/96 & 143.26 & 235.44 & Taiwan & $1945 / 49$ & 398.73 & 82 \\
\hline Germany & 1920/23 & 29525.71 & -1.68 & Tajikistan & 1995 & 78.1 & 234 \\
\hline Georgia & 1993/94 & 196.72 & 163 & Turkmenistan & 1993 & 62.5 & 179.6 \\
\hline Greece I & $1942 / 44$ & 11288 & 464.93 & Ukraine & 1991/93 & 249 & 376 \\
\hline Greece II & $1944 / 46$ & 126.02 & 1.27 & Yugoslavia & 1990 & 58.82 & 110.15 \\
\hline \multicolumn{8}{|c|}{ Notes: * Geometric Average of Quarter. Serbia with Montengro: New Yugoslav Republic. } \\
\hline
\end{tabular}

Bernholz has tried to explain the successes or failures of the reforms to end the inflations in the three categories considered by comparing the differences in the institutional changes contained in them. We follow this approach, but substitute his verbal by a more compelling quantitative analysis. Table 2.2 presents the most important characteristics of the attempted reforms. It is mainly based on the description of the reforms provided by Bernholz (2003, Tables 8.2, 8.4, 8.6 and 8.7). For a detailed discussion the reader is referred to the source. In our analysis we consider five qualitative institutional indicators which may be important for the success of a currency reform for theoretical reasons. The first two indicators cover the existence of domestic and foreign credits to replace money financing of 
the government budget, the third indicator refers to the introduction of central bank independence, the fourth indicator shows the existence of limited credit lines of the government at the central bank. The credible fixing of the exchange rate is the fifth indicator. Moreover, we added a sixth qualitative indicator for the economic system which takes the value of one for a centrally planed economy and is zero otherwise. This variable is included because many aspects of controlling inflation are different in a centrally planned compared to a market economy. First, there exists a monetary overhang at the beginning of the reforms. Second, prices have been mostly fixed by government agencies below the level of market equilibrium. With the beginning of the reforms these regulations are mostly abolished, and together with the monetary overhang lead to substantial price increases. Third, the tax system is not well developed in a centrally planned economy, since in this system the government mainly finances itself by taking what it needs directly from the mostly state-owned enterprises. With the beginning of the transition process it thus takes time to establish an adequate tax system. This usually leads to strong initial pressures to finance the budget deficit by money creation. The inflationary developments resulting from these factors may in turn lead to inflationary expectations which increase the velocity of money and worsen further the prospects for a successful currency reform (Bernholz, 1992).

Finally we should mention that we use the term central bank independence in a wide sense which differs from the meaning of the term in the literature on political business cycles and (moderate) inflation bias of a discretionary monetary policy. What is important in our context is only the legal safeguard that does not allow the central bank or the monetary authority to finance government budget deficit except within narrow limits. Therefore, we do not attempt to differentiate the degree of central bank independence among the countries included. 
Table 2: Institutional Characteristics of Currency Reforms

\begin{tabular}{|c|c|c|c|c|c|c|c|c|c|c|c|}
\hline Country & $\begin{array}{l}\text { Dom. } \\
\text { Credit }\end{array}$ & $\begin{array}{l}\text { For. } \\
\text { Credit }\end{array}$ & $\begin{array}{l}\text { CB } \\
\text { indep }\end{array}$ & $\begin{array}{l}\text { Budg. } \\
\text { Fin.rule }\end{array}$ & $\begin{array}{l}\text { Fixed } \\
\text { Ex.ra. }\end{array}$ & Country & $\begin{array}{l}\text { Dom. } \\
\text { Credit }\end{array}$ & $\begin{array}{l}\text { For. } \\
\text { Credit }\end{array}$ & $\begin{array}{l}\text { CB } \\
\text { indep. }\end{array}$ & $\begin{array}{l}\text { Budg. } \\
\text { Fin.rule }\end{array}$ & $\begin{array}{l}\text { Fixed } \\
\text { Ex.ra. }\end{array}$ \\
\hline Austria & yes & yes & yes & yes & yes & Hungary I & yes & yes & yes & yes & yes \\
\hline Argentina I & no & no & no & no & no & Hungary II & yes & yes & yes & no & no \\
\hline Argentina II & yes & yes & yes & yes & yes & Israel & yes & yes & no & no & no \\
\hline Armenia & yes & yes & yes & no & no & Kazakhstan & no & yes & no & no & no \\
\hline Azerbaijan & yes & yes & no & no & no & Kyrgyzstan & yes & yes & yes & no & no \\
\hline Belarus & yes & yes & no & no & no & Moldova & yes & yes & no & no & no \\
\hline Bolivia & no & no & no & no & no & Nicaragua & no & yes & yes & no & yes \\
\hline Brazil I & yes & no & no & no & no & Peru & yes & no & yes & yes & no \\
\hline Brazil II & yes & yes & no & no & no & Poland I & yes & no & yes & no & yes \\
\hline Bulgaria & yes & yes & yes & yes & yes & Poland II & yes & yes & no & no & no \\
\hline China & yes & no & no & no & no & Serbia & no & no & no & no & no \\
\hline Congo (Zaire) & yes & no & no & no & no & Soviet Union & yes & no & yes & no & no \\
\hline France & yes & no & no & no & no & Taiwan & no & no & no & no & yes \\
\hline Germany & no & yes & yes & no & yes & Tajikistan & yes & yes & yes & no & no \\
\hline Georgia & yes & yes & no & no & no & Turkmenistan & yes & yes & no & no & no \\
\hline Greece I & yes & yes & no & no & no & Ukraine & yes & yes & no & no & no \\
\hline Greece II & no & yes & yes & no & yes & Yugoslavia & yes & no & no & no & no \\
\hline
\end{tabular}

\section{Econometric Results from an Ordered Probit Model}

This section presents the results of an application of an ordered probit model to the data set described in section 2. This model is used instead of a standard regression model since the target variable of the reform (the inflation rate in the post reform period) is very high for some unsuccessful reforms. These outlying observations would probably have a strong influence on the regression estimates. The ordinal variable to be explained is the variable $y$ taking the value 2 for a fully successful reform, 1 for a less successful reform and 0 for a least successful or completely unsuccessful reform, respectively. Six dummy explanatory variables are considered: $x 1=D C D$ (limited domestic reform credit 1 , otherwise 0 ), $x 2=$ DFC (foreign reform credit 1, otherwise 0 ), $x 3=\mathrm{DCB}$ (independence of central bank 1, otherwise 
0 ), $x 4=D B$ (no government finance by money creation 1 , otherwise 0 ) and, $x 5=D F I X$ (credibly fixed exchange rate 1 , otherwise 0 ), and $x 6=D S$ (centrally planned economy 1 , otherwise 0$)^{1}$, respectively.

The ordered probit model is based on a regression model for one underlying non- observable variable $y^{*}$ with a normally identically and independently distributed error term. If the observable ordinal variable $y$ takes the value s this indicates that the latent $y^{*}$ lies between two unknown bounds which have to be estimated jointly with the regression coefficients:

$$
\begin{aligned}
& y_{i}^{*}=\sum_{j=1}^{k} \beta_{j} x_{j i}+\varepsilon_{i} \\
& y_{i}=s, \text { if } \gamma_{s-1}<y_{i}^{*} \leq \gamma_{s}, \quad s=0,1 \ldots, M-1 \\
& \gamma_{-1}=-\infty, \gamma_{M}=\infty
\end{aligned}
$$

An increase in one of the regressors increases the probability of observing a higher value of $y$ (i.e. a greater success of the reform) if the corresponding regression coefficient is larger than zero. The estimation results obtained with our data set are reported in Table 1 . We show the results for the alternative definition of a most successful reform (with a post reform annual rate of inflation $<10 \%$ ) as well as for a restricted variant of the model including only indicators

\footnotetext{
$1 \quad$ The centrally planned economies in our sample are: The successor states of the Soviet Union contained in our sample (Armenia, Azerbaijan, Belarus, Georgia, Kazakhstan, Kyrgyztan, Moldova Takijikistan,, Turkmeninstan, Ukraine) as well as Poland II, Serbia and Yugoslavia, The results are, however, robust with respect to the exclusion of Serbia and Yugoslavia.
} 
Table 3: Estimates of a orderd probit model for 34 hyperinflations, standard errors (Huber/White QML) in parentheses

$$
y_{i}^{*}=\beta_{1} D C D+\beta_{2} D C F+\beta_{3} D C B+\beta_{4} D B+\beta_{5} D F I X+\beta_{6} D S+\varepsilon_{i}
$$

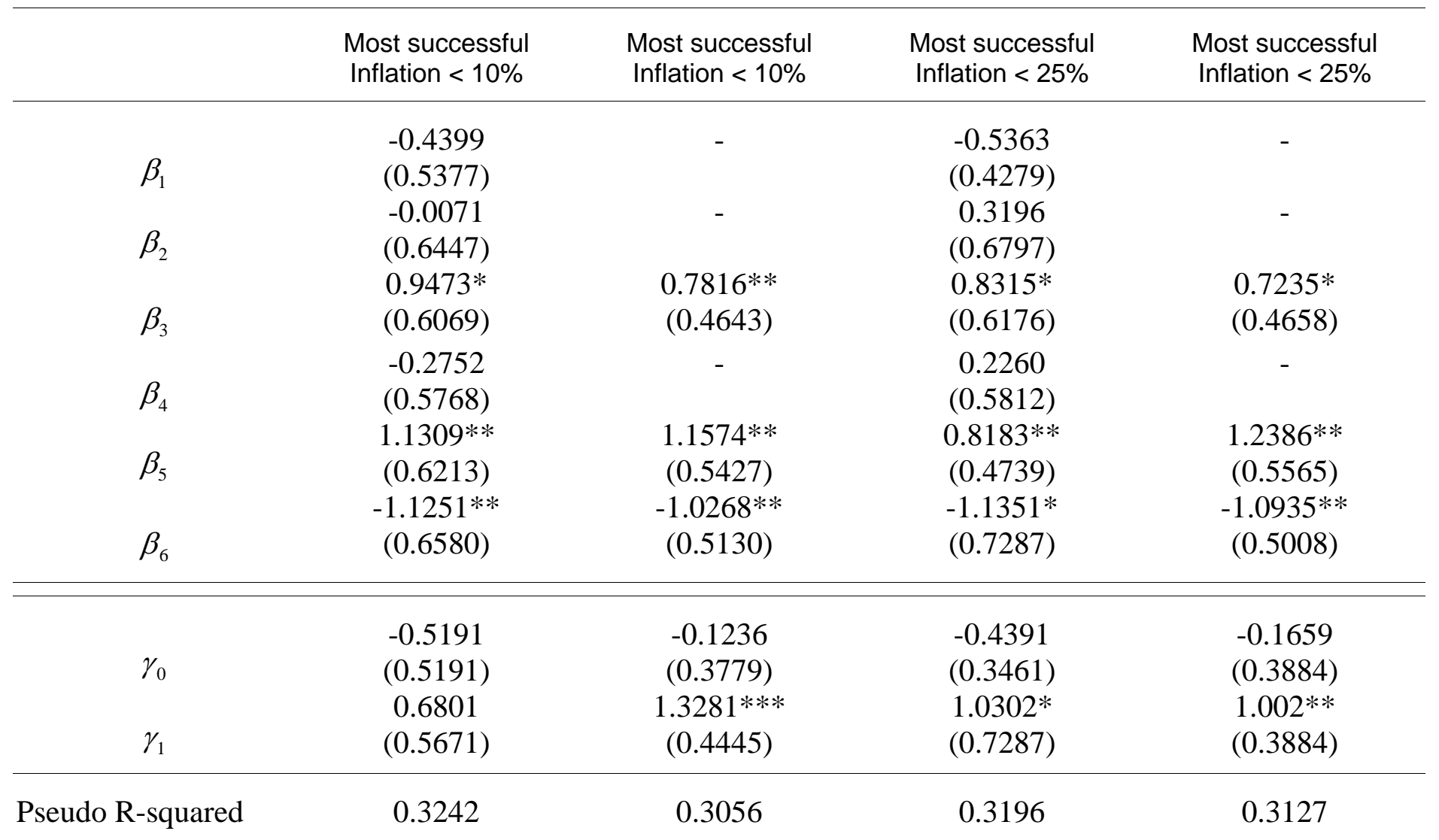

*, ** and ${ }^{* * *}$ denotes statistical significance (one sided) at the 10,5 and 1 percent level, respectively.

Table 3 indicates that three indicators are statistically significant at the 10 percent level for the degree of success of a currency reform, namely central bank independence, fixed exchange rate and, with a negative sign, the centrally planned economy indicator. All other indicators are clearly insignificant and we get statistical significance at the 5 percent level for the three apparently important indicators if we exclude the insignificant ones. The coefficient for the fixed exchange rate is usually the largest in absolute value and implies that the adoption of a credibly fixed exchange rate is highly relevant for successful currency reforms. Indeed, the magnitude of the estimates indicates that the adoption of a credibly fixed exchange rate pushes the latent variable over the second limit point in the region with full success in a market economy. In a centrally planned economy more safeguards are required in the 
sense that according to our restricted estimates we need both measures DCB and DFIX to arrive at a successful currency reform.

\section{Conclusion}

The estimation of an ordered probit model for currency reforms of 31 hyperinflations and three big inflations of the $20^{\text {th }}$ century showed that the introduction of an independent central bank and the adoption of a fixed exchange rate are statistically significant indicators for the success of a currency reform. The provision of domestic and foreign credits for government budged finance has no statistically significant effect on the success of a currency reform. This indicates that the provision of credits to the government may raise doubts about its intention to solve its budget problem in a sustainable manner. Most interestingly legal restrictions on budget financing do not seem to be relevant when the legal status of the central bank and the exchange rate regime are controlled for.

Finally, currency reforms are more difficult in formerly centrally planned economies than in market economies. 


\section{References}

Bernholz, P.(1992), Property, Markets, and Money, Cato Journal 11 (3), 409-424.

Bernholz, P. (2003), Monetary Regimes and Inflation; History, Economic and Political Relationships, Edward Elgar, Cheltenham UK.

Bomberger, W. A. and Makinen, Gail E. (1983), The Hungarian Hyperinflation and Stabilization of 1945-46, Journal of Political Economy, 91 (5), 801-824.

Cagan, Philipp (1992), Hyperinflation: Theory. The Palgrave Dictionary of Money and Finance, vol. 2, London and Basingstoke: Macmillan, 323-326.

Makinen, Gail E. (1984), The Greek Stabilization of 1944-46. American Economic Review 74, 106774.

Makinen, Gail E. (1992), Hyperinflation: Experience. The Palgrave Dictionary of Money and Finance, vol. 2, London and Basingstoke: Macmillan, 326-328.

Paldam, M (1994), The Political Economy of Stopping High Inflation, European Journal of Political Economy 10, 135-168

Sargent, T. (1982), The End of four Big Inflations. In R. E. Hall (Editor): Inflation: Causes and Effects, University of Chicago Press, Chicago. 